\title{
Article \\ Techno-Economic Analysis of Commercial Size Grid-Connected Rooftop Solar PV Systems in Malaysia under the NEM 3.0 Scheme
}

\author{
Alaa A. F. Husain ${ }^{1}$, Maryam Huda Ahmad Phesal ${ }^{1, *}$, Mohd Zainal Abidin Ab Kadir ${ }^{2}$ (D) \\ and Ungku Anisa Ungku Amirulddin 1(D) \\ 1 Institute of Power Engineering, Universiti Tenaga Nasional, Kajang 43000, Malaysia; \\ alaa.a.f.husain@gmail.com (A.A.F.H.); anisa@uniten.edu.my (U.A.U.A.) \\ 2 Advanced Lightning, Power and Energy Research Centre (ALPER), Universiti Putra Malaysia (UPM), \\ Serdang 43400, Malaysia; mzk@upm.edu.my \\ * Correspondence: hmaryam@uniten.edu.my
}

check for updates

Citation: Husain, A.A.F.; Phesal, M.H.A.; Ab Kadir, M.Z.A.; Ungku Amirulddin, U.A. Techno-Economic Analysis of Commercial Size Grid-Connected Rooftop Solar PV Systems in Malaysia under the NEM 3.0 Scheme. Appl. Sci. 2021, 11, 10118. https://doi.org/10.3390/ app112110118

Academic Editors: Luis Hernández-Callejo, Sergio Nesmachnow and Sara Gallardo Saavedra

Received: 22 September 2021 Accepted: 19 October 2021 Published: 28 October 2021

Publisher's Note: MDPI stays neutral with regard to jurisdictional claims in published maps and institutional affiliations.

Copyright: (c) 2021 by the authors. Licensee MDPI, Basel, Switzerland. This article is an open access article distributed under the terms and conditions of the Creative Commons Attribution (CC BY) license (https:/ / creativecommons.org/licenses/by/ $4.0 /)$.

\begin{abstract}
Commercial grid-connected rooftop solar PV systems are widely applied worldwide as part of affordable and clean energy initiatives and viable long-term solutions for energy security. This is particularly true in a crowded city where space is a constraint and at the same time, there are unutilized rooftops. With the recently announced Net Energy Metering (NEM) 3.0, commercial buildings in Malaysia can apply up to 75\% capacity of the maximum demand (MD), which can be connected to the grid. Apart from reducing electricity bills, the owner can offset energy for 10 years. This paper presents a design analysis with the details of the sizing of a rooftop PV system. The PVsyst software tool is used to estimate the energy produced by a $380 \mathrm{kWp}$ system, and this study provides a financial analysis to evaluate the profitability of the system with a particular interest in commercial buildings under the NEM 3.0 policy, which has resulted in 8.4 years return of investment (ROI). PVsyst is a software used to size the PV system and provides technical, financial, and environmental analysis. This in-depth analysis could provide a useful case study for asset owners in deciding the way forward for sustainable energy production, cost saving, and combating the energy security issue, since Malaysia is blessed with an abundance of sunshine throughout the year.
\end{abstract}

Keywords: rooftop solar PV; net energy metering (NEM); maximum demand; PV software

\section{Introduction}

\subsection{Motivation}

Energy plays a key role in the advancement and development of human activity and a brighter future. However, the current energy supply is not enough to cover the demand in the coming years, and it causes damage to the environment [1]. Solar energy is an abundant green source that can replace fossil fuel. Since the sun is available everywhere, solar energy is widely used by most countries, including developing countries. It is used in Malaysia under various government policies. These policies are implemented to encourage the use of green energy and support small and large projects [2,3]. Most implemented PV system are residential or large-scale PV system in Malaysia. Under NEM, residential fill in most of the quota.

Hybrid PV systems are not a popular practice in Malaysia. Due to the lack of analysis proving the variability of implementing a system that can satisfy the electrical needs of the consumer and at the same time reduce the cost of electricity, the consumer pays yearly. NEM 3.0 approved a rooftop PV system implementation that is connected to the utility grid for commercial buildings. The consumer that falls under this category only is able to implement $75 \%$ of the maximum demand according to the size of the PV power plant. This gives the motivation to test this policy profitability financially and assess its technical and environmental impact. 


\subsection{Brief on Solar PV Policies in Malaysia}

Malaysia began to implement polices to encourage renewable energy storage in 2011 with Feed-in Tariff [4-11]. In 2016, the scheme changed to NEM, which was modified in 2019. These polices are implemented with the aim of meeting the target for installing renewable energy in Malaysia. In achieving the aspirational goal of having 20\% renewable energy in the country's national installed capacity mix by 2025 , the major renewable resource that will contribute to the RE mix is solar energy [12-14].

Three types of NEM have been implemented in recent years [14] i.e., NEM 2016 (NEM 1.0), NEM 2019 (NEM 2.0), and recently, NEM 2021 (NEM 3.0) [15-17]. In NEM 2016, Equation (1) is the total cost of the electricity bill generated monthly for the customer and is computed by deducting the price of the power generated by PV, which is MYR 0.31, from the price of the power consumed by the customer from the grid. The power generated by PV and the price of generated energy are computed using Equations (2) and (3), respectively.

$$
\text { Bill price }=\text { price of consumed energy }- \text { price of generated energy }
$$

Price of generated energy $=$ power generated by PV $\times$ displaced $\cos t$ by the grid

Price of consumed energy $=$ power consumed by the customer $\times$ price tariff

However, in 2019, the NEM strategy changed, since not many customers installed PV systems based on the poor financial return from this policy. The policy now offsets the customer cost for every $1 \mathrm{kWh}$ produced by the PV system with $1 \mathrm{kWh}$ consumed from the grid. Equations (4) and (5) shows the monthly electricity bill computed after deducting the power generated by the customer from the power consumed:

$$
\begin{gathered}
\text { Total power }=\text { power consumed from grid }- \text { power generated by PV } \\
\text { Electricity bill }=\text { total power } \times \text { price tariff. }
\end{gathered}
$$

Based on other case studies, this policy has a better financial return than NEM 2016 [10]. For commercial and industrial systems, the maximum capacity of the PV system installed is $1 \mathrm{MW}$ or $75 \%$ of maximum demand (MD) of their existing installation, or $60 \%$ of the fuse rating of the transformer [12,13].

For domestic or residential consumers, the maximum capacity of the PV systems installed is less than or equal to $12 \mathrm{~kW}$ for a single phase or $72 \mathrm{~kW}$ for a three-phase system [11]. NEM 3.0 consists of three programs, each of which are assigned to a specific market sector. The first program is NEM Rakyat, which covers the residential segment [18,19]. A $100 \mathrm{MW}$ capacity is allocated to this program, effective from 1 February 2021 [20]. The program applies the one-to-one NEM 3.0 policy for 10 years [21]. The allowed maximum PV installation capacity for the domestic consumer is 4 and $10 \mathrm{~kW}$ for single-phase and three-phase NEM consumers, respectively. The second program, called NEM GoMEn, covers government ministries and entities and has $100 \mathrm{MW}$ allocated for solar power implementation. The program also applies a one-to-one offset for 10 years [22]. The maximum allowed PV installation capacity is $1000 \mathrm{~kW}$ per single account with a maximum of $75 \%$ from the $\mathrm{MD}$, i.e., the average of the recorded MD of the past year or the declared MD for consumers with less than a one-year record. This is applicable for medium-voltage consumers and for low-voltage consumers not exceeding $60 \%$ of the fuse rating (for direct meters) or $60 \%$ of the current transformer (CT) rating of the metering current transformers, as shown in Table 1 [23].

Solar PV systems have many types based on different categories such as grid dependency. Some of the PV systems connect to the grid and use it as a battery storage alternative, and some systems are totally independent from the grid and use battery storage to store energy for nighttime use [16]. There are also hybrid systems using the grid as storage for excess PV energy or in case PV does not meet their demand, especially at night; at the same time, they use battery storage for a different reason [24,25]. This study focuses on 
the grid-connected PV system [26]. Most of the available studies focus on the technical advancement on the designed under the old used policies for small or large-scale PV systems in Malaysia. This paper provides detailed financial analysis for a rooftop commercial-sized PV system under the recent policy announced in 2021. The paper analysis proves the profitability of such projects under the recent policy and clarifies the limitation of a system implemented under NEM3.0.

Table 1. PV policies in Malaysia applied to commercial buildings.

\begin{tabular}{|c|c|c|c|c|}
\hline Policy & Year & Definition & Notes & Ref. \\
\hline $\mathrm{FiT}$ & 2011-2016 & $\begin{array}{l}\text { The concept of FiTs is that the } \\
\text { yield of the user-generated } \\
\text { photovoltaic system is sold to the } \\
\text { utility grid at a price set by the } \\
\text { utility network. Two meters are } \\
\text { installed; one is used to count the } \\
\text { electricity consumed by the user, } \\
\text { and the second meter measures } \\
\text { the kWh produced by the PV } \\
\text { system and sent to the grid. }\end{array}$ & $\begin{array}{l}\text { It was the first policy } \\
\text { implemented in Malaysia. }\end{array}$ & [6-8] \\
\hline NEM 1.0 & 2016-2019 & $\begin{array}{l}\text { NEM enables customers to } \\
\text { produce and use solar energy to } \\
\text { satisfy demand. The extra PV } \\
\text { electricity will be exported to the } \\
\text { grid. This surplus power is } \\
\text { subsequently offset by a rate of } \\
\text { MYR 0.31/kWh from the next } \\
\text { electricity bill. }\end{array}$ & $\begin{array}{l}\text { The energy produced by the } \\
\text { PV system is consumed by the } \\
\text { owner and the excess energy is } \\
\text { exported to the grid. There is } \\
\text { not money offset-only a } \\
\text { reduction in the next } \\
\text { electricity bill. }\end{array}$ & {$[15,20,27,28]$} \\
\hline NEM 2.0 & 2019-2021 & $\begin{array}{l}\text { This policy allows a consumer } \\
\text { who produces photovoltaic energy } \\
\text { to export the excess energy to the } \\
\text { grid, and each kWh is } \\
\text { compensated by another kWh } \\
\text { from the next electricity bill. }\end{array}$ & $\begin{array}{l}\text { Each one kWh exported to the } \\
\text { grid will be offset from the } \\
\text { next electricity bill by } \\
\text { deducting the value of one } \\
\text { kWh starting with the highest } \\
\text { tariff. In the previous NEM, } \\
\text { the energy exported to the grid } \\
\text { would only be paid at a } \\
\text { displaced cost of MYR } \\
0.31 / \mathrm{kWh} \text {. }\end{array}$ & {$[16,21,29]$} \\
\hline NEM 3.0 & 2021-2023 & $\begin{array}{l}\text { Similar concept to NEM 2.0, apart } \\
\text { from that it permits indirect } \\
\text { connection to commercial } \\
\text { buildings. The allowed installed } \\
\text { capacity is } 75 \% \text { of MD for } \\
\text { commercial buildings. }\end{array}$ & $\begin{array}{l}\text { A hybrid system/indirect } \\
\text { connection is allowed }\end{array}$ & {$[30]$} \\
\hline
\end{tabular}

\subsection{Grid-Connected PV System}

The primary component of grid-connected PV systems is the power conditioning unit (PCU). The PCU converts the DC power produced by the PV array into AC power as per the voltage and power quality requirements of the utility grid. A bidirectional interface is made between the PV system, AC output circuits, and the electric utility network; typically, an onsite distribution panel or service entrance [30-32] allows the AC power produced by the PV system to either supply onsite electrical loads or to back feed the grid when the PV system output is greater than the onsite load demand. This safety feature is required in all grid-connected solar PV [33].

One of the important components of an on-grid system is net metering. Standard service meters are odometer-type counting wheels that record power consumption at a service point by means of a rotating disc, which is connected to the counting mechanism. 
The rotating discs operate by an electro physical principle called the eddy current. Digital electric meters make use of digital electronic technology that registers power measurement by solid-state current and voltage sensing devices that convert analog measured values into binary values that are displayed on the meter using liquid crystal display (LCD) readouts [20]. Inverters are the main difference between a grid-connected system and a standalone system. The inverters must have the line frequency synchronization capability to deliver the excess power to the grid. Net meters have the capability to record consumed or generated power in an exclusive summation format. The recorded power registration is the net amount of power consumed - the total power used minus the amount of power that is produced by the solar power cogeneration system [34,35]. Net meters are supplied and installed by utility companies that provide grid-connection service systems [36]. Net metered solar PV power plants are subject to specific contractual agreements and are subsidized by state and municipal governmental agencies.

The usage profile (i.e., operation hours- $24 \mathrm{~h}$ or not) of electricity is divided from Monday to Sunday into on-peak hours from 08:00 a.m. to 10:00 p.m. and off-peak hours from 10:00 p.m. to 08:00 a.m. Each period has a different tariff rate that is clarified in the next Table 2. In order to understand the PV system's financial benefit and policy rules, we must first identify the tariff that the user's electricity falls under. After that, the policy suited to the user is selected.

Table 2. Site Information.

\begin{tabular}{cc}
\hline Type & Information \\
\hline Location & Bangi, Selangor (Klang Valley) \\
\hline Slope azimuth & 180 \\
\hline Roof type & Clay and concrete tiles \\
\hline
\end{tabular}

\subsection{Contribution and Paper Organization}

New polices have been implemented over the last few years in Malaysia. This is to encourage the use of renewable energy and increase its share in the energy mix. The latest implemented policy is NEM 3.0, which allows $75 \%$ of an MD rooftop PV system to be connected to the utility grid. Due to the fact that this policy is newly implemented for this category of system size, not much analysis is available that gives detailed technical and financial information. This paper provides a case study that guides the user to size the system under the recent NEM 3.0 policy and achieve final profit saving. Section 2 discusses the methodology involved to achieve the final design. Section 3 defines the load consumption and system configuration. Section 4 explains the load profile of the selected case study with the adopted method in sizing the PV system. Finally in Section 5, the PVsyst tool provides a technical and financial analysis with some discussions, and a conclusion provided at the end of the paper.

\section{Methodology}

Traditionally, the PV system size is obtained through the electricity profile of the consumer where the final design cost of the $\mathrm{kWh}$ produced using the PV system must be less than the price of the grid tariff. The PV system size must be adjusted by calculating the sun peak hours in the specific location and the average electricity used daily for a year of consumption, plus the available roof space to install the PV system; thus, the PV system size is computed. However, based on the recent NEM 3.0 policy in Malaysia, only $75 \%$ of MD is allowed to be installed and connected to the grid [37,38].

The components of the PV system are selected through the power rating decided by the manufacturers for the appliances, in conjunction with a careful estimation of how long each appliance will need power [39]. However, this can apply for small PV installation. In a large PV plant, the electricity demand based on the previous year of the electricity profile is thoroughly studied. 
The PVsyst tool is commercially available software that is used to simulate solar PV projects. This study used a PV system for modeling purposes. The PVsyst software library contains detailed data about the most common photovoltaic modules, inverters, and all that is needed for a photovoltaic system project. Furthermore, it records losses due to the partial shadowing effects, mismatches between connected PV modules, wiring losses, inverter losses, and the effect of the ambient temperature variations on its electrical output power calculation. This functionality makes it a precise tool to estimate the amount of electrical energy produced by a designed system [40,41].

\section{System Configuration}

The grid-connected PV system configuration is simple compared with the off-grid PV system, which requires battery storage. It contains PV solar plants, an inverter, a meter, wiring, and a mounting system, as shown in Figure 1. The solar PV plant converts the photons in the sunlight into electricity that runs as DC [26,27]. The electricity enters the inverter, and then, it is transformed into AC to suit the appliances of the building [28]. The extra electricity is exported to the utility grid where it is measured by a meter. The meter also measures the electricity imported from the utility grid.

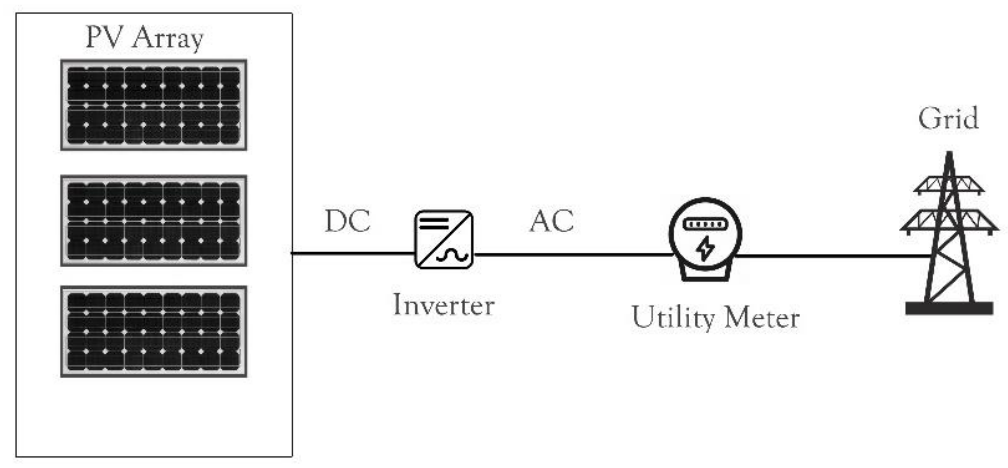

Figure 1. Grid-connected PV system configuration.

The site selected in this case study is denoted as building A, which is described in Table 2. The building is located in the Bangi area in Selangor, Malaysia and has a lot of empty spaces on the roof without any shading from nearby buildings or trees. The roof was sturdy and made of clay and concrete tiles, which make it possible to install a PV system that the roof will bear its weight.

\section{Load Profile}

In order to implement the NEM on the commercial building, load profile information was collected and analyzed. The collected data determined the size of the solar PV system. At present, the customer is using $100 \%$ electricity from the utility grid. From Table 3, it can be seen that the total yearly energy consumption was 3,194,184 $\mathrm{kWh}$ with an average monthly cost of MYR 125,787. It can be noticed that JAN and MAR are much lower than the other peak hours in other months due to system measurement dysfunction. These two months were excluded when computing the average peak hour.

Table 3. Customer electricity profile for the year 2019.

\begin{tabular}{ccccc}
\hline Month & Demand, kWh & MD, kW & MD, MYR & Cost, MYR \\
\hline JAN & 141,265 & 95 & 4285 & 47,957 \\
FEB & 127,680 & 552 & 24,895 & 43,727 \\
MAR & 346,075 & 95 & 4285 & 129,553 \\
APRIL & 100,093 & 502 & 22,640 & 100,094 \\
MAY & 357,702 & 494 & 22,279 & 108,422 \\
JUN & 283,652 & 499 & 22,505 & 113,256 \\
\hline
\end{tabular}


Table 3. Cont.

\begin{tabular}{ccccc}
\hline Month & Demand, kWh & MD, kW & MD, MYR & Cost, MYR \\
\hline JULY & 344,294 & 514 & 23,181 & 133,032 \\
AUG & 342,547 & 503 & 22,685 & 342,158 \\
SEP & 299,892 & 502 & 22,640 & 118,990 \\
OCT & 331,863 & 491 & 22,144 & 128,770 \\
NOV & 335,701 & 498 & 22,460 & 130,132 \\
DEC & 283,513 & 496 & 22,370 & 113,350 \\
TOTAL & $3,194,184$ & - & - & $1,509,441$ \\
Average & 274,523 & $505^{*}$ & 19,697 & 125,787 \\
\hline
\end{tabular}

* exclude of Jan and March.

\section{System Sizing}

The system size was designed based on the customer's electrical profile during the year 2019. The peak sun hours of 2019 were $4.4 \mathrm{~h}$ on average based on Table 1 . The total yearly electrical consumption was 3,194,184 kWh. The building falls under the 'C Tariff' with an electricity price during peak hours of MYR $0.365 / \mathrm{kWh}$, an off-peak price of MYR $0.224 / \mathrm{kWh}$, and an MD of MYR 45/kW.

In order to calculate the system size, we obtained the MD point of every month of in 2019 and calculated the average point, which was $505 \mathrm{~kW}$.

$$
\text { Size of PV system }=\mathrm{MD} \times 75 \%=505 \mathrm{~kW} \times 75 \%=378.75 \mathrm{~kW} \cong 380 \mathrm{~kW}
$$

The allowed PV system size to connect to the utility grid is $380 \mathrm{~kW}$, which is $16 \%$ of the total electricity demand. The annual global solar irradiation of the location of the Building A was measured using the PVsyst program, producing a value of $4.4144 \mathrm{kWh} / \mathrm{m}^{2}$. The average ambient temperature was $27.4^{\circ} \mathrm{C}$. Table 4 shows the monthly global solar irradiation and the output of a one $\mathrm{kW}$ PV system at that location.

Table 4. Monthly global solar irradiation and the output of a $1 \mathrm{~kW}$ PV system.

\begin{tabular}{|c|c|c|c|c|}
\hline Month & $\begin{array}{c}\text { AC System } \\
\text { Output (kWh) }\end{array}$ & $\begin{array}{l}\text { Solar Radiation } \\
\left(\mathrm{kWh} / \mathrm{m}^{2} / \text { day }\right)\end{array}$ & $\begin{array}{l}\text { Irradiance } \\
\left(\mathrm{W} / \mathrm{m}^{2}\right)\end{array}$ & $\begin{array}{c}\text { DC Array } \\
\text { Output (kWh) }\end{array}$ \\
\hline 1 & 103.19 & 4.44 & 137.60 & 107.85 \\
\hline 2 & 95.95 & 4.55 & 127.47 & 100.29 \\
\hline 3 & 104.86 & 4.52 & 140.15 & 109.62 \\
\hline 4 & 94.78 & 4.19 & 125.55 & 99.10 \\
\hline 5 & 89.40 & 3.80 & 117.80 & 93.58 \\
\hline 6 & 85.31 & 3.77 & 113.08 & 89.36 \\
\hline 7 & 89.52 & 3.80 & 117.91 & 93.78 \\
\hline 8 & 94.33 & 4.01 & 124.28 & 98.72 \\
\hline 9 & 95.52 & 4.21 & 126.16 & 99.85 \\
\hline 10 & 98.78 & 4.21 & 130.44 & 103.25 \\
\hline 11 & 95.13 & 4.20 & 125.87 & 99.45 \\
\hline 12 & 95.95 & 4.05 & 125.55 & 100.34 \\
\hline Total & 1142.72 & 49.74 & 1511.86 & 1195.19 \\
\hline
\end{tabular}

After sizing the system according to $75 \% \mathrm{MD}$, the PV system production could only cover $380 \mathrm{~kW}$ of electricity demand. While this is seen lower compared to the $2671.2 \mathrm{~kW}$ PV plant where electricity demand was met $100 \%$, this still could reduce the electricity bill and cost saving, particularly since the MD for electricity is recorded during the peak hours.

\section{PV System Analysis Using PVsyst Tools}

PVsyst is a design tool that provides optimization tools for sizing grid-connected, standalone, and pumping PV systems based on the location on the map. The tool also depends on the consumer electricity profile and the demands of electricity. It also provides a financial visibility for the designed project with environmental impact measured in 
tonnes. The program contains the latest used technology in the market, which can be selected during the sizing process. It can also calculate the loss in the system [23]. On the other hand, there are many other online program tools that help calculate the system size based on the location and demand of the user such as HOMER and PVWATT. However, PVsyst is chosen in this work for its flexibility when choosing the modules used as well as more specification details as opposed to PVWATT. The annual energy yield for the proposed PV power plant was defined as the amount of energy fed into the grid after due consideration of all kinds of generation and distribution losses. The solar PV-based power plant comprises the optical energy input (which is essentially dependent on the geographical/seasonal/climatic and operating parameters with time) and the electrical output (which depends on the technical specifications of the electrical appliances in use). Industry standard software PVsyst V6.8.1 was used for the Energy Generation Assessment.

The system consisted of 810 units of $470 \mathrm{Wp}$ PV modules that connected in 81 strings with 10 modules in each string connected in series. The total nominal power of the plant was $380 \mathrm{kWp}$, as shown in Table 5.

Table 5. PV module details.

\begin{tabular}{cc}
\hline Parameters & Values \\
\hline PV module size & $470 \mathrm{Wp}$ \\
Number of modules & 810 units \\
Nominal (STC) & $380 \mathrm{kWp}$ \\
Modules & 81 strings $\times 10$ in series \\
$P_{\mathrm{mpp}}$ & $707 \mathrm{~V}$ \\
$\mathrm{U}_{\mathrm{mpp}}$ & $501 \mathrm{~A}$ \\
Module area & $1751 \mathrm{~m}^{2}$ \\
\hline
\end{tabular}

The inverter used for this system design was a $100 \mathrm{kWac}$ power inverter. Three inverters were used for the whole system. The inverters' operating system was 630-1000 V and the DC to AC power conversion ratio was 1.27, as shown in Table 6.

Table 6. Installed inverter details.

\begin{tabular}{cc}
\hline Parameters & Values \\
\hline Unit Nom Power & $100 \mathrm{kWac}$ \\
Number of inverters & 3 units \\
Total power & $380 \mathrm{kWac}$ \\
Operating voltage & $630-1000 \mathrm{~V}$ \\
Pnom ratio (DC:AC) & 1.27 \\
\hline
\end{tabular}

The proposed $380 \mathrm{~kW}$ solar PV plant is expected to generate about $510 \mathrm{MWh}$ of energy in the first year of operation at a net Capacity Utilization Factor (CUF) of $18 \%$ at the metering point, as per Table 7 . Thereafter, an annual degradation factor of $2.5 \%$ for the first year and $0.7 \%$ thereafter in production has been considered for mono crystalline modules for financial calculations.

The CUF-Capacity Utilization Factor compares $380 \mathrm{~kW}$ solar power plants with other $380 \mathrm{~kW}$ power plants that run $24 \times 7$ for 365 days in terms of how much energy is generated. If the $380 \mathrm{~kW}$ solar power plant generates $100 \mathrm{~s}$ of Wh for 365 days running on $24 \times 7$ and we have some $50 \mathrm{~s}$ of Wh at the end of our solar plant, its capacity utilization would be $50 \%$. The average ratio is 0.803 . The PV system's nominal power output is $380 \mathrm{~kW}$. Due to various factors such as site location and system losses, the power capacity of the system was reduced, as shown in Figure 2. The energy yield was calculated based on the south-facing array surface. The expected plant production for different probability scenarios (the probability of meeting a generation value) is also presented in Figure 2. 
Table 7. Balance and main results.

\begin{tabular}{ccccccccc}
\hline & $\begin{array}{c}\text { GlobHor } \\
\mathbf{k W h} / \mathbf{m}^{\mathbf{2}}\end{array}$ & $\begin{array}{c}\text { DiffHor } \\
\mathbf{k W h} / \mathbf{m}^{\mathbf{2}}\end{array}$ & $\begin{array}{c}\mathbf{T}_{\mathbf{C}} \mathbf{A m b} \\
{ }^{\circ} \mathbf{C}\end{array}$ & $\begin{array}{c}\text { Globlnc } \\
\mathbf{k W h} / \mathbf{m}^{\mathbf{2}}\end{array}$ & $\begin{array}{c}\text { GlobEff } \\
\mathbf{k W h} / \mathbf{m}^{\mathbf{2}}\end{array}$ & $\begin{array}{c}\text { EArray } \\
\mathbf{M W h}\end{array}$ & $\begin{array}{c}\text { E_Grid } \\
\mathbf{M W h}\end{array}$ & $\begin{array}{c}\text { E_Grid } \\
\mathbf{M W h}\end{array}$ \\
\hline JAN & 133.6 & 79.58 & 27.21 & 140.4 & 137.0 & 44.38 & 43.10 & 0.806 \\
FEB & 131.6 & 81.85 & 27.84 & 135.4 & 132.0 & 42.72 & 41.55 & 0.806 \\
MAR & 153.8 & 88.56 & 28.27 & 153.6 & 149.9 & 48.24 & 46.89 & 0.802 \\
APR & 142.7 & 73.33 & 27.86 & 138.6 & 135.0 & 43.44 & 42.15 & 0.799 \\
MAY & 144.8 & 77.78 & 28.71 & 136.7 & 132.5 & 42.88 & 41.59 & 0.799 \\
JUN & 133.0 & 70.24 & 28.20 & 124.4 & 120.7 & 39.19 & 37.98 & 0.802 \\
JUL & 134.4 & 81.91 & 28.20 & 126.7 & 122.7 & 39.98 & 38.77 & 0.804 \\
AUG & 136.7 & 82.95 & 28.09 & 131.4 & 127.7 & 41.52 & 40.27 & 0.805 \\
SEP & 133.6 & 69,76 & 27.38 & 132.1 & 128.8 & 41.45 & 40.20 & 0.799 \\
OCT & 140.5 & 86.62 & 27.67 & 143.0 & 139.6 & 45.20 & 43.88 & 0.806 \\
NOV & 124.6 & 69.35 & 26.85 & 130.2 & 127.4 & 41.12 & 39.87 & 0.804 \\
DEC & 121.3 & 67.82 & 27.27 & 128.1 & 125.0 & 40.37 & 39.13 & 0.802 \\
YEAR & 1630.5 & 929.75 & 27.80 & 1620.5 & 1578.1 & 510.49 & 495.39 & 0.803 \\
\hline
\end{tabular}

\section{Normalized Production and Loss Factors: Nominal power $381 \mathrm{kWp}$}

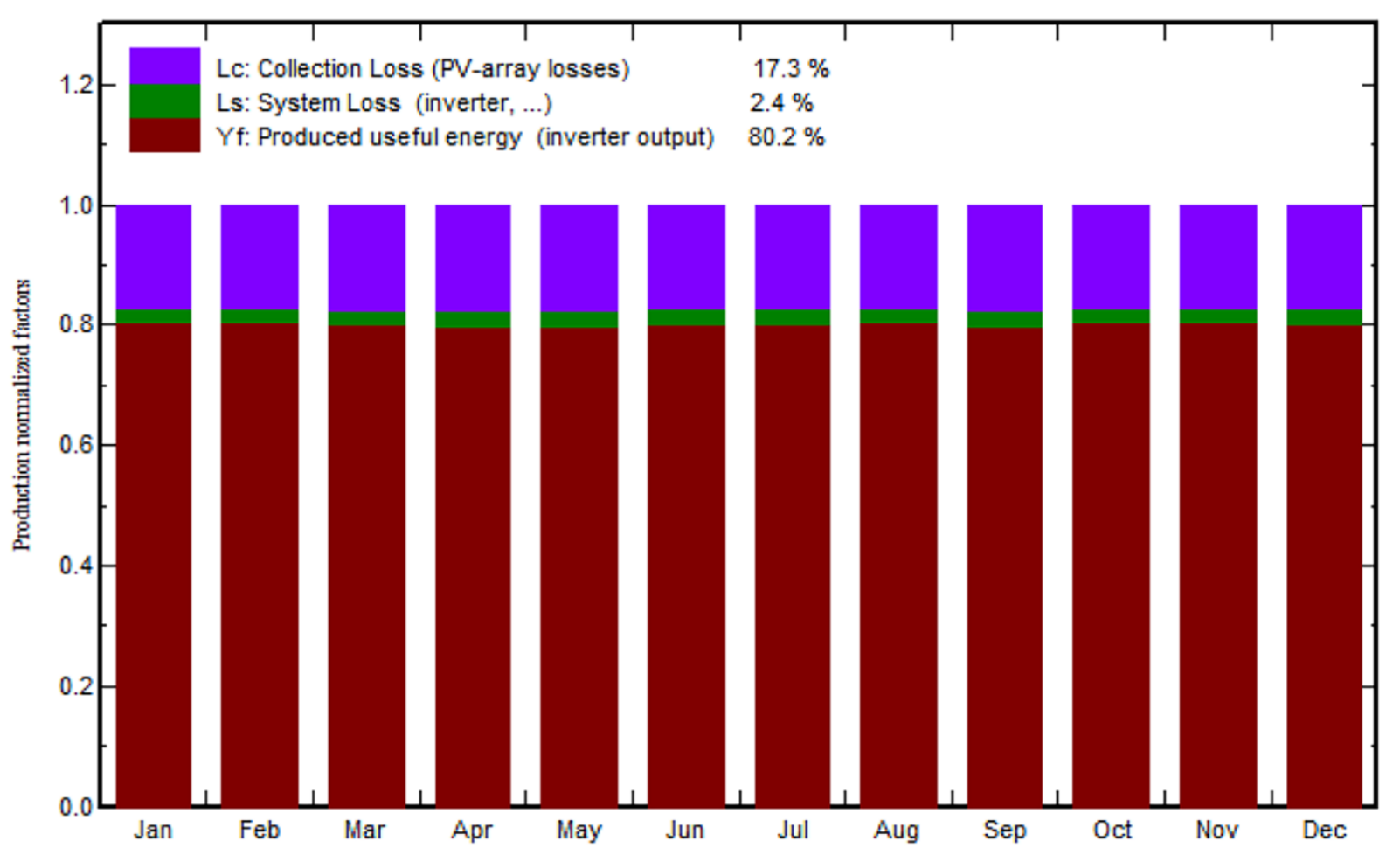

Figure 2. Normalized production (per installed $\mathrm{kWp}$ ).

The yield factor was defined to be a factor consolidating all the system losses that occurred across this power plant. The major losses that occurred during the operation of the solar PV power plant were temperature loss, module mismatch loss, and DC to AC conversion losses. Figure 3 presents the loss diagram over the whole year. The diagram represents the energy flows in the system and the losses from every parts. Figure 3 shows that the largest losses came from temperature with $7.77 \%$, while the inverter loss was $1.47 \%$, which is expected from the manufacturing datils of the components. 


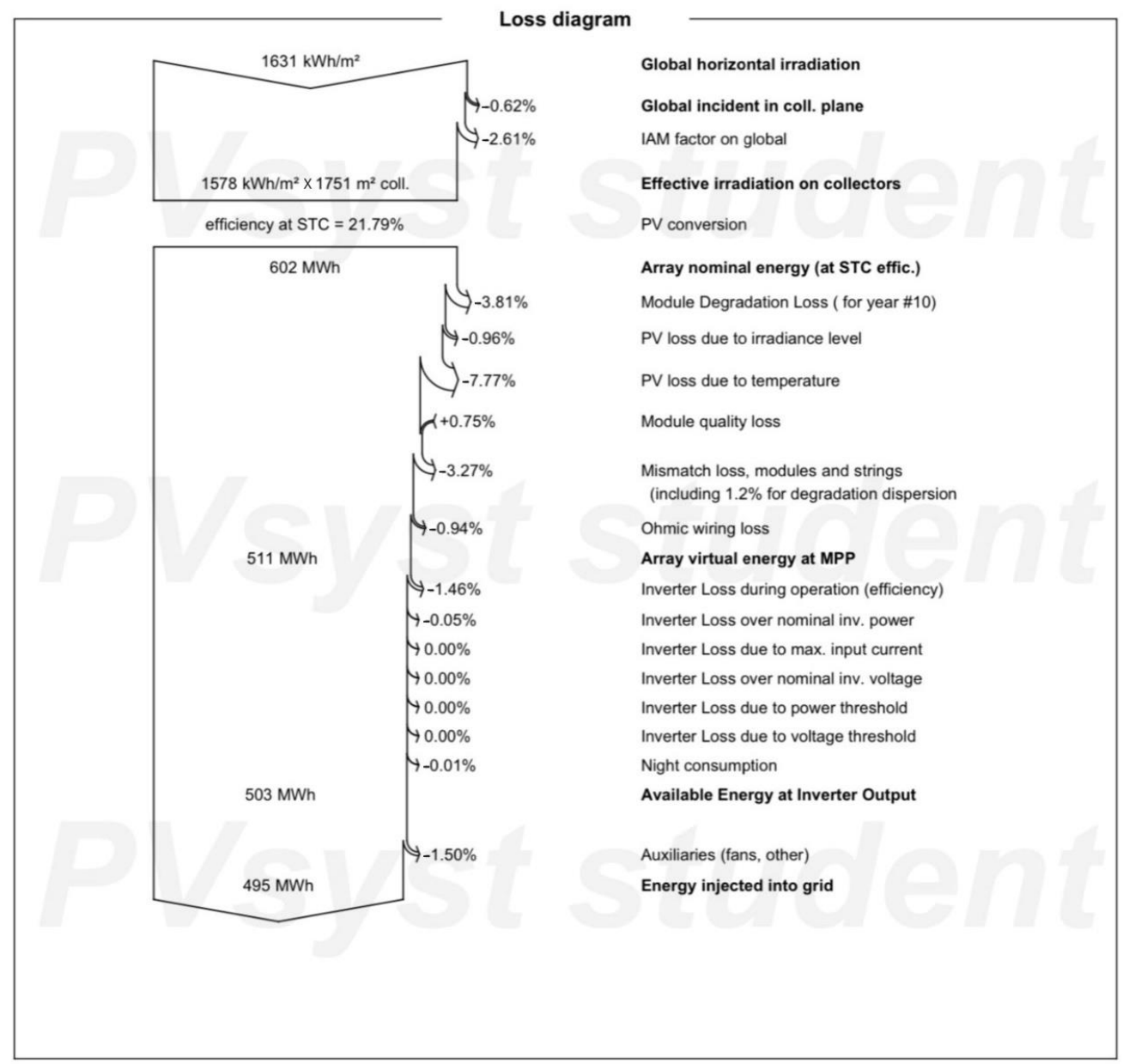

Figure 3. Loss diagram of energy for a year of expected production flowing through the PV system energy using PVsyt.

\section{Financial Analysis}

The objective of financial analysis is to assess the financial viability of the project from the perspective of a project developer so as to arrive at a suitable investment decision. As shown in Table 8, all of the costing is in Malaysian Ringgit (MYR). The system cost included the cost of the PV modules, inverters, mounting materials, other components (cables, mounting system, charge controller and utility meter, etc.), the balance of the system, and interconnection [29].

Table 8. Cost details of the PV system components.

\begin{tabular}{cccc}
\hline Item & Quantity Units & Cost, MYR & Total, MYR \\
\hline PV modules & 810 & 932 & 755,121 \\
Inverter & 3 & 80,332 & 240,996 \\
Other components & 1 & 289,195 & 289,195 \\
Installation & 810 & 238 & 192,797 \\
Operating cost & & 5141 & 5141 \\
& Total & & $1,478,109$ \\
\hline
\end{tabular}

Based on Table 8, the total installation cost is MYR 1,478,108.8; the operating cost is MYR 5141.25/year produced energy, and the cost of the produced energy (LCOE) is MYR $0.130 / \mathrm{kWh}$. After a detailed analysis, it was concluded that the project is financially viable and that it will have a project lifetime of 25 years (starting year 2022), financing cost at MYR 1,478,108.8, and a payback period of 8.4 years. The net present value (NPV) is MYR 
2,459,445.1, and the return on investment (ROI) would be $166.4 \%$, as shown in Figure 4 . Due to the degradation of the PV system, the profit starts to decrease in the last years of the project lifetime.

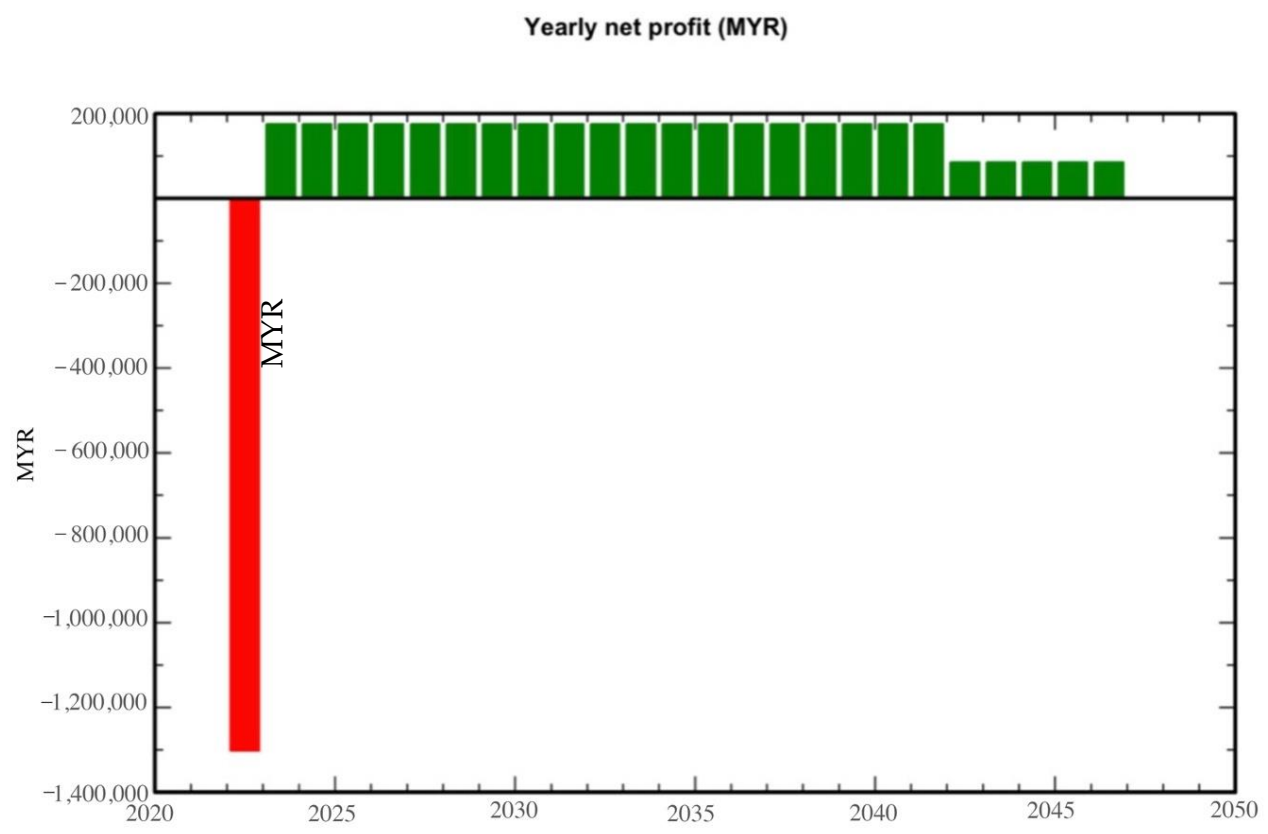

Figure 4. Yearly net profit in MYR during the lifetime of a $380 \mathrm{~kW}$ PV system.

From Figure 5, it can be observed that from the ninth year, the project will be in the positive $y$-axis, beginning to generate profit from the initial investment. Cash flow was calculated based on (1) the tariff rate for each unit $(\mathrm{kWh})$ by the solar plant against (2) the fixed cost of the investment and (3) the operational cost annually. By calculating the difference as $=(1)-(2+3)$, we derived the amount shown in the graph. All the costs were equalized for a lifespan of 25 years. For the first 8.4 years, the investment cost is greater than the profit amount; then, the breakeven point is reached, and positive values result in annual profits from the PV system.

Cumulative cashflow (MYR)

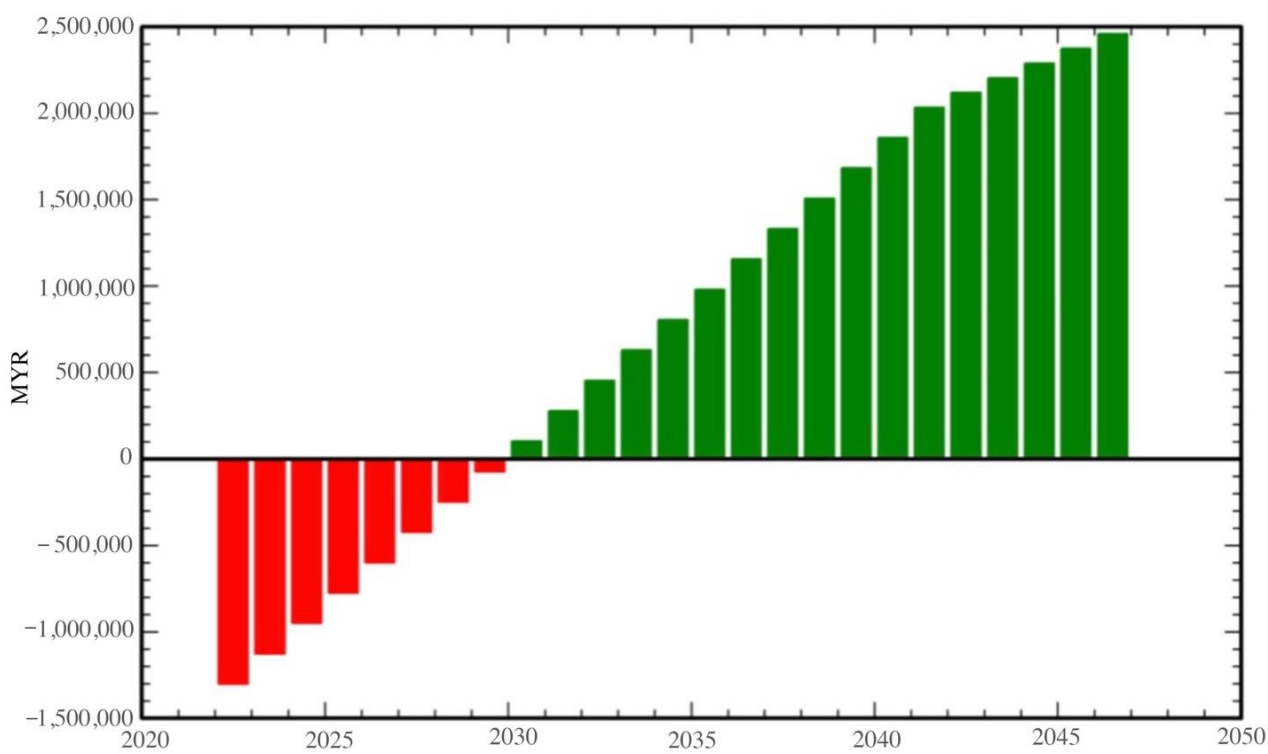

Figure 5. Cumulative cashflow in MYR during the lifetime of $380 \mathrm{~kW}$ PV system. 


\section{Environmental Impact}

The implementation of solar power has been greatly encouraged due to its influence on reducing carbon emissions. Thus, it is important to measure the environmental benefit of using solar energy instead of fossil fuel. Figure 6 shows the amount of $\mathrm{CO}_{2}$ emission saved during the lifetime of the project. The calculations depend majorly on the value of the life cycle emissions (LCA), which represent $\mathrm{CO}_{2}$ emissions associated with a given component or quantity of energy. This includes the total life cycle of a component or the amount of energy, including production, operation, maintenance, disposal, etc. The rationale behind the carbon footprint tool is that the electricity generated by the photovoltaic system will replace the same amount of electricity in the existing grid. If the carbon footprint of the electricity generation on the grid is more than the PV system per $\mathrm{kWh}$, carbon dioxide emissions will be reduced. From Figure 6, $\mathrm{CO}_{2}$ emission is negative until the last 10 years of the project; then, it becomes positive due to the fact that the PV system installed satisfies only $16 \%$ of the consumer demand. The rest of the demand is met by the grid of utilities using traditional fossil fuel energy that causes $\mathrm{CO}_{2}$ emissions in the air.

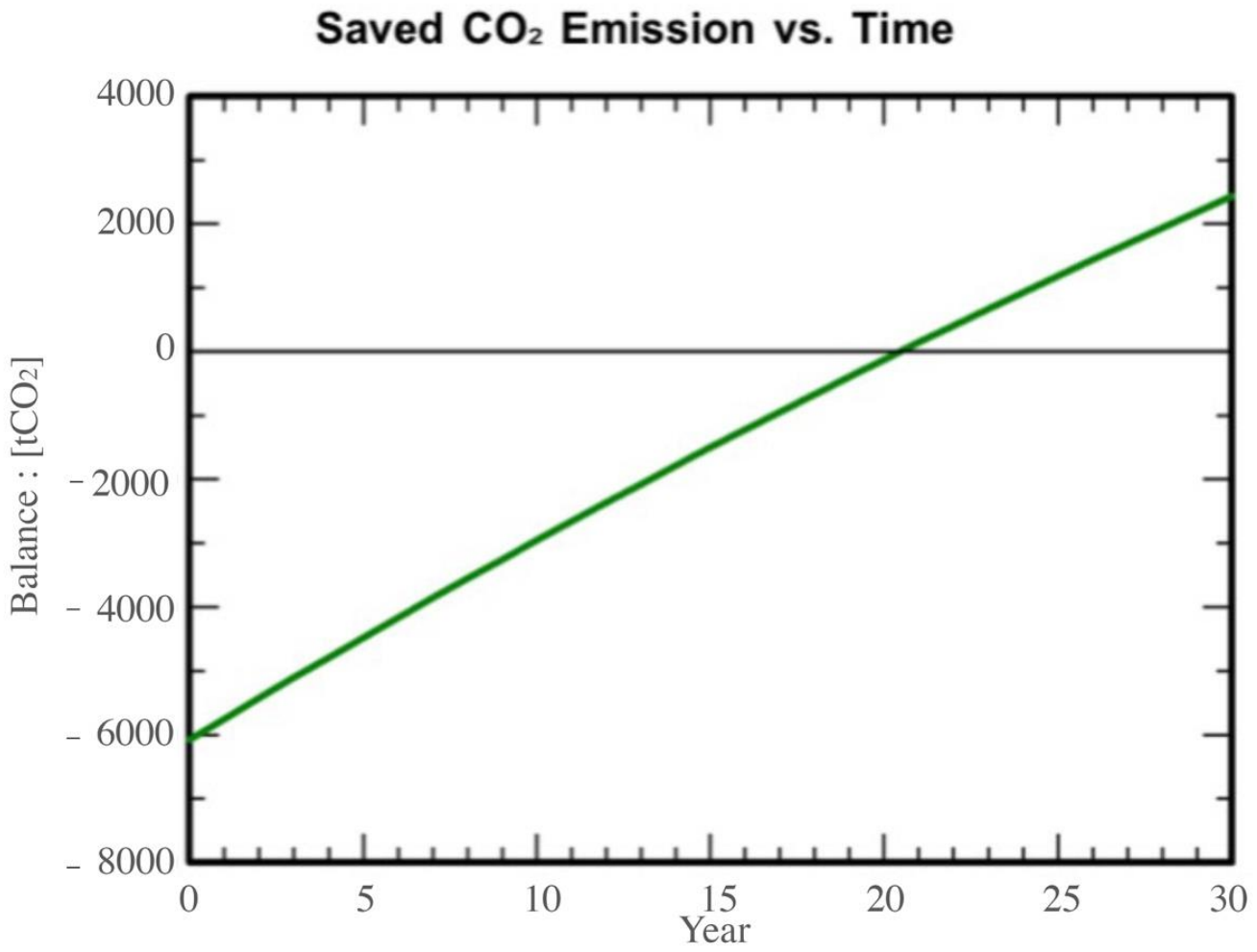

Figure 6. $\mathrm{CO}_{2}$ emission reduction vs. time.

\section{Discussion}

The average annual solar radiation at the proposed site on the horizontal surface is about $1598 \mathrm{kWh} / \mathrm{m}^{2}$ (as per NASA-SSE satellite data) [42], which is adequate for the installation of the solar PV ground-mounted utility scale system. Annual expected generation for the entire solar PV project is $510 \mathrm{MWh}$ /year, where the evaluation is based on a probabilistic approach for the interpretation of the simulation results over several years.

The $380 \mathrm{~kW}$ grid-connected PV system consists of $810 \mathrm{PV}$ solar modules grouped into $20 \times 81$ strings with each string containing 10 modules in series. The output of the strings is pooled in the array junction box through $4 \mathrm{~mm}^{2}$ photovoltaic DC cables. The output from the junction box is fed to the three grid-tied inverters. The grid-connected inverter is used as a power conditioning unit. DC and AC distribution cabinets contain protective components for the safety of the system.

Based on the results obtained in PVsyst tools, one day of energy production by the PV system plant was measured and compared with the total electricity demand in one day, as 
shown in Figure 2. From the figure, it can be seen that only $16 \%$ of the electricity demand is covered. This is due to the restricted rule of NEM that only allows $75 \%$ of the MD of electricity to be connected to the utility grid.

Although the PV system plant would only cover $16 \%$ of the total electricity demand, the reduction in the electricity bill would be significant since the solar PV plant produces energy during the on-peak hours. The electricity rates are MYR $0.365 / \mathrm{kWh}$ and MYR $0.224 / \mathrm{kWh}$ during on-peak and off-peak hours, respectively. Moreover, the MD point during the day can also be covered by the PV plant or can be reduced significantly. Since this plant is small compared with the electricity demand of the building, it will not export electricity except for on the weekends. It is expected that the electricity will be used on a daily basis, as shown in Figure 7.

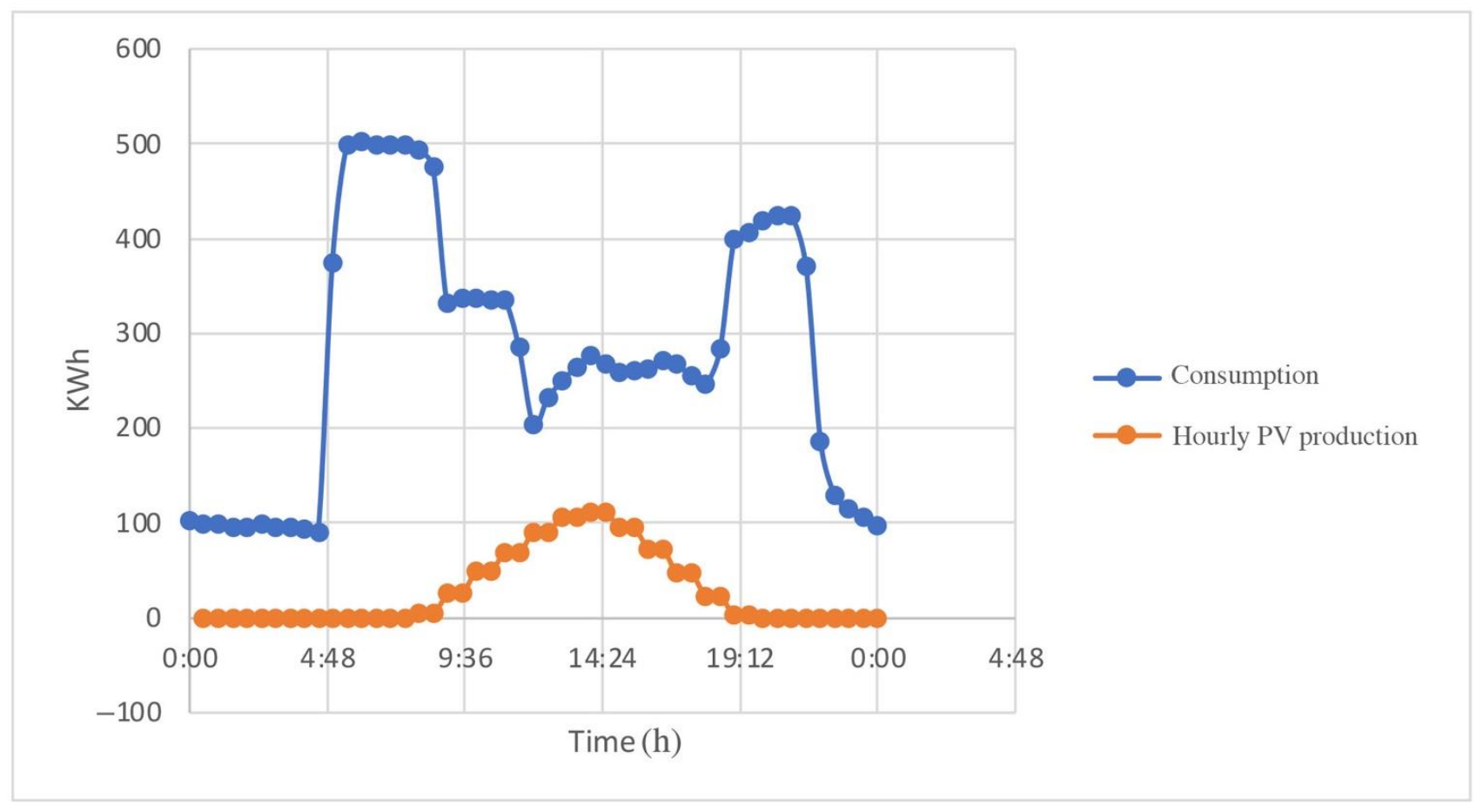

Figure 7. One-day energy consumption and PV production.

\section{Conclusions}

A techno-economic analysis of commercial-size grid-connected rooftop solar PV systems has been presented in this paper, taking into account the recently announced NEM 3.0 scheme in 2021. The availability of the solar irradiance at that location is relatively high i.e., $4.4144 \mathrm{kWh} / \mathrm{m}^{2}$ day throughout the year. The size of the PV plant was calculated based on the consumer electricity profile of one year. The average MD of $505 \mathrm{~kW}$ was considered for sizing $75 \%$ of the system. Due to the fact that the power output of the PV system is $510 \mathrm{MWh}$ /year, the PV system size would only cover $16 \%$ of the yearly electricity demand. After sizing the PV system, it was modeled and simulated using the PVsyst program. The system performance showed promising results of $510.49 \mathrm{MWh}$ produced yearly from the plant. A financial analysis was carried out with an estimation of the system price based on percentage and rates from the original country of the building location. Based on the analysis, the project's ROI is in 8.4 years, and the LCOE is at MYR $0.130 / \mathrm{kWh}$, which is less than both tariffs from the utility during on-peak and off-peak hours. The net present value (NPV) is MYR 2,459,445.1, and ROI is positive and equal to $166.4 \%$. The system would have a positive environmental impact with a reduction in the emission of $\mathrm{CO}_{2}$ at least until the end of the tenure agreement. The results from this project analysis show good promise 
and benefits not just for energy and cost savings but also in terms of utilizing the dead spaces on the rooftop of buildings.

Author Contributions: Conceptualization; methodology; resources; data curation; writing-original draft preparation, A.A.F.H.; visualization; supervision, M.H.A.P.; supervision, writing-review and editing, M.Z.A.A.K.; project administration, U.A.U.A. All authors have read and agreed to the published version of the manuscript.

Funding: This research was funded by Universiti Tenaga Nasional through UNITEN BOLD Scholarship.

Institutional Review Board Statement: Not applicable.

Informed Consent Statement: Not applicable.

Data Availability Statement: Not applicable.

Conflicts of Interest: The authors declare no conflict of interest. The funders had no role in the design of the study; in the collection, analyses, or interpretation of data; in the writing of the manuscript, or in the decision to publish the results.

\section{References}

1. Tsoutsos, T.; Frantzeskaki, N.; Gekas, V. Environmental impacts from the solar energy technologies. Energy Policy 2005, 33, $289-296$. [CrossRef]

2. Vaka, M.; Walvekar, R.; Rasheed, A.K.; Khalid, M. A review on Malaysia's solar energy pathway towards carbon-neutral Malaysia beyond COVID'19 pandemic. J. Clean. Prod. 2020, 273, 122834. [CrossRef]

3. SEDA. Sustainable Energy Development Authority Malaysia. “Grid Parity; Displaced Cost". Available online: http://www3 .seda.gov.my (accessed on 10 October 2021).

4. Gomesh, N.; Daut, I.; Irwanto, M.; Irwan, Y.; Fitra, M. Study on Malaysian's Perspective towards Renewable Energy Mainly on Solar Energy. Energy Procedia 2013, 36, 303-312. [CrossRef]

5. Fayaza, H.; Rahimb, N.A.; Saidura, R.; Solangi, K.H.; Niaz, H.; Hossaina, M.S. Solar Energy Policy: Malaysia vs. De-veloped Countries. In Proceedings of the IEEE Conference on Clean Energy and Technology (CET), Kuala Lumpur, Malaysia, 27-29 June 2011; pp. 374-378.

6. Zhang, H.L.; Van Gerven, T.; Baeyens, J.; Degrève, J. Photovoltaics: Reviewing the European Feed-in-Tariffs and Changing PV Efficiencies and Costs. Sci. World J. 2014, 2014, 1-10. [CrossRef] [PubMed]

7. Chua, S.C.; Oh, T.H.; Goh, W.W. Feed-in tariff outlook in Malaysia. Renew. Sustain. Energy Rev. 2011, 15, 705-712. [CrossRef]

8. Wong, S.L.; Ngadi, N.; Abdullah, T.A.T.; Inuwa, I. Recent advances of feed-in tariff in Malaysia. Renew. Sustain. Energy Rev. 2015, 41, 42-52. [CrossRef]

9. Solangi, K.H.; Saidur, R.; Rahim, N.A.; Islam, M.R.; Fayaz, H. Current solar energy policy and potential in Malay-sia, 3rd. In Proceedings of the International Conference on Science and Technology, Pulau Pinang, Malaysia, 12-13 December 2008.

10. Saadatian, O.; Haw, L.C.; Mat, S.B.; Sopian, K. Perspective of sustainable development in Malaysia. Int. J. Energy Environ. 2012, 6, 260-267.

11. New Economic Model for Malaysia Part 1. Available online: https://www.pmo.gov.my/dokumenattached/NEM_Report_I.pdf (accessed on 10 October 2021).

12. Raza, M.; Alshebami, A.S.; Sibghatullah, A. Factors Influencing Renewable Energy Technological Innovation in Malaysia. Int. J. Energy Econ. Policy 2020, 10, 573-579. [CrossRef]

13. Islam, S.Z.; Othman, M.L.; Saufi, M.; Omar, R.; Toudeshki, A. Photovoltaic modules evaluation and dry-season energy yield prediction model for NEM in Malaysia. PLoS ONE. 2020, 15, e0241927. [CrossRef] [PubMed]

14. Husain, A.A.; Phesal, M.H.A.; Kadir, M.Z.A.; Amirulddin, U.A.U. Short Review on recent solar PV policies in Malaysia. E3s Web Conf. 2020, 191, 1002. [CrossRef]

15. Poullikkas, A.; Kourtis, G.; Hadjipaschalis, I. A review of net metering mechanism for electricity renewable energy sources. Int. J. Energy Environ. 2013, 4, 975-1002.

16. Abdullah, W.S.W.; Osman, M.; Ab Kadir, M.Z.A.; Verayiah, R. The potential and status of renewable energy de-velopment in Malaysia. Energies 2019, 12, 2437. [CrossRef]

17. Christoforidis, G.C.; Chrysochos, A.; Papagiannis, G.; Hatzipanayi, M.; Georghiou, G.E. Promoting PV energy through net metering optimization: The PV-NET Project. In Proceedings of the 2013 International Conference on Renewable Energy Research and Applications (ICRERA), San Diego, CA, USA, 17-22 October 2013.

18. Razali, A.H.; Abdullah, P.; Hassan, M.Y.; Hussin, F. Comparison of New and Previous Net Energy Metering (NEM) Scheme in Malaysia. Elektr. J. Electr. Eng. 2019, 18, 36-42. [CrossRef]

19. Dutta, S.; Ghosh, D.; Mohanta, D.K. Optimum solar panel rating for net energy metering environment. In Proceedings of the 2016 International Conference on Electrical, Electronics, and Optimization Techniques (ICEEOT), Chennai, India, 3-5 March 2016; IEEE: Piscataway, NJ, USA, 2016; pp. 2900-2904. [CrossRef] 
20. Abdul, R.D. Sustainable Energy, Suruhanjaya Tenaga Energy Commission. Available online: http://gtalcc.gov.my/wp-content/ uploads/2021/08/Sustainable-Energy-Energy-Efficiency-Renewable-Energy.pdf (accessed on 21 October 2021).

21. Zainudin, N.; Sharifuddin, N.S.I.; Osman, S.; Jusoh, Z.M.; Paim, L.; Zainalaludin, Z.; Nordin, N. Validating of So-lar Energy Acceptance Measurements Among Malaysian Households. Int. J. Soc. Sci. Res. 2020, 2, $20-31$.

22. Tan, R.H.; Chow, T. A Comparative Study of Feed in Tariff and Net Metering for UCSI University North Wing Campus with 100 kW Solar Photovoltaic System. Energy Procedia 2016, 100, 86-91. [CrossRef]

23. Husain, A.A.F.; Phesal, M.H.A.; Ab Kadir, M.Z.A.; Amirulddin, U.A.U.; Junaidi, A.H.J. A Decade of Transitioning Malaysia toward a High-Solar PV Energy Penetration Nation. Sustainability 2021, 13, 9959. [CrossRef]

24. Chaurey, A.; Deambi, S. Battery storage for PV power systems: An overview. Renew. Energy 1992, 2, 227-235. [CrossRef]

25. Ip, A.H.; Thon, S.; Hoogland, S.; Voznyy, O.; Zhitomirsky, D.; Debnath, R.K.; Levina, L.; Rollny, L.R.; Carey, G.H.; Fischer, A.H.; et al. Hybrid passivated colloidal quantum dot solids. Nat. Nanotechnol. 2012, 7, 577-582. [CrossRef] [PubMed]

26. Alwaeli, A.H.A.; Sopian, K.; Kazem, H.A.; Chaichan, M.T. Photovoltaic/Thermal (PV/T) systems: Status and future prospects. Renew. Sustain. Energy Rev. 2017, 77, 109-130. [CrossRef]

27. Marańda, W.; Piotrowicz, M. Sizing of photovoltaic array for low feed-in tariffs. In Proceedings of the 21st International Conference Mixed Design of Integrated Circuits and Systems (MIXDES), Lublin, Poland, 19-21 June 2014; pp. 405-408.

28. Murdan, A.P.; Jeetun, A.K. Simulation of a Single Phase Grid-tied PV System under Net-Metering Scheme. In Proceedings of the 2021 IEEE Power and Energy Conference at Illinois (PECI), Urbana, IL, USA, 1-2 April 2021; IEEE: Piscataway, NJ, USA, 2021; pp. 1-6. [CrossRef]

29. Ratnam, E.L.; Weller, S.R.; Kellett, C. Scheduling residential battery storage with solar PV: Assessing the benefits of net metering. Appl. Energy 2015, 155, 881-891. [CrossRef]

30. For Solar Photovoltaic Installation under the Programme of NEM Rakyat and NEM GoMEn in Peninsular Malaysia. Available online: http:/ / www.seda.gov.my/reportal/nem/ (accessed on 10 October 2021).

31. Zainuddin, H.; Salikin, H.R.; Shaari, S.; Hussin, M.Z.; Manja, A. Revisiting solar photovoltaic roadmap of tropical malaysia: Past, present and future. Pertanika J. Sci. Technol. 2021, 29, 1567-1578. [CrossRef]

32. Gitizadeh, M.; Fakharzadegan, H. Battery capacity determination with respect to optimized energy dispatch schedule in grid-connected photovoltaic (PV) systems. Energy 2014, 65, 665-674. [CrossRef]

33. Seepromting, K.; Chatthaworn, R.; Khunkitti, P.; Kruesubthaworn, A.; Siritaratiwat, A.; Surawanitkun, C. Distribution company investment cost reduction analysis with grid-connected solar PV allocation in power distribution system. Int. J. Smart Grid Clean Energy 2020. [CrossRef]

34. Subramaniam, U.; Vavilapalli, S.; Padmanaban, S.; Blaabjerg, F.; Holm-Nielsen, J.B.; Almakhles, D. A Hybrid PV-Battery System for ON-Grid and OFF-Grid Applications-Controller-In-Loop Simulation Validation. Energies 2020, 13, 755. [CrossRef]

35. Yusoff, N.F.; Zakaria, N.Z.; Zainuddin, H.; Shaari, S. Mounting Configuration factor for building integrated photovol-taic and retrofitted grid-connected photovoltaic system. Sci. Lett. 2017, 11, 1-6.

36. Watts, D.; Valdés, M.F.; Jara, D.; Watson, A. Potential residential PV development in Chile: The effect of Net Metering and Net Billing schemes for grid-connected PV systems. Renew. Sustain. Energy Rev. 2015, 41, 1037-1051. [CrossRef]

37. Humada, A.M.; Aaref, A.M.; Hamada, H.M.; Sulaiman, M.H.; Amin, N.; Mekhilef, S. Modeling and characterization of a grid-connected photovoltaic system under tropical climate conditions. Renew. Sustain. Energy Rev. 2017, 82, 2094-2105. [CrossRef]

38. Mekhilef, S.; Barimani, M.; Safari, A.; Salam, Z. Malaysia's renewable energy policies and programs with green aspects. Renew. Sustain. Energy Rev. 2014, 40, 497-504. [CrossRef]

39. Mansur, T.M.N.T.; Baharudin, N.H.; Ali, R. A Comparative Study for Different Sizing of Solar PV System under Net Energy Metering Scheme at University Buildings. Bull. Electr. Eng. Inform. 2018, 7, 450-457. [CrossRef]

40. Irwan, Y.; Amelia, A.; Irwanto, M.; Fareq, M.; Leow, W.; Gomesh, N.S.I. Stand-Alone Photovoltaic (SAPV) System Assessment using PVSYST Software. Energy Procedia 2015, 79, 596-603. [CrossRef]

41. Gharakhani Siraki, A.; Pillay, P.D. Comparison of PV System Design Software Packages for Urban Applications; IEEE: Piscataway, NJ, USA, 2010.

42. NASA-SSE Satellite Data. Available online: http:// eosweb.larc.nasa.gov/sse/ (accessed on 10 October 2021). 